\title{
New species of Glossosomatidae from Bolivia with new records from Bolivia and northwestern Argentina (Trichoptera: Glossosomatidae)
}

\author{
P.A. Rueda Martín ${ }^{1}$, F.M. Gibon ${ }^{2}$ \\ ${ }^{1}$ CONICET-INSUE, Miguel Lillo 205, CP 4000, San Miguel de Tucumán, Tucumán, Argentina. \\ ${ }^{2}$ IRD (UR131), Antenne au Museum national d'Histoire Naturelle, 57 rue Cuvier, C.P.26, 75231 Paris, France.
}

\begin{abstract}
Seven new species of Glossosomatidae are described from Bolivia. The seven new Bolivian species are: Mexitrichia collegarum n. sp., M. eduardoi n. sp., M. marini n. sp, M. usseglioi n. sp, Protoptila alumnorum n. sp, P. goitiai n. sp and P. myriamae n. sp. 18 species are recorded at the moment from Bolivia and northwestern Argentina: Merionoptila wigodzinskyi, Mexitrichia albolineata, M. bolivica, M. pocita, M. punensis, M. simla, M. argentinica, M. paraenchrysa, M. wygodzinskii, Protoptila dubitans, P. misionensis and the seven new species. A list of species of Glossosomatidae from Bolivia and northwestern Argentina is provided with new distributional records.
\end{abstract}

Keywords: Trichoptera, Glossosomatidae, Bolivia, Argentina, new species, new records.

\section{Introduction}

The Neotropical Region comprises four biogeographic subregions (Morrone 2001): subregion Caribean, subregion Amazónica, subregion Chaqueña y subregion Paranaense. Two subregions are present in Bolivia and northwestern Argentina. The Amazonian subregion, containing the "Yungas" province, and the Chacoan subregion containing "Chaco" province. The biotic composition of these areas could be similar.

The Trichoptera fauna from Bolivia and northwestern Argentina is poorly known (Angrisano 1995) and the family Glossosomatidae family is no exception. This family is cosmopolitan (Flint et al. 1999) and is represented in South America by the subfamily Protoptilinae. The adults of Glossosomatidae are usually smaller than $3 \mathrm{~mm}(2-6 \mathrm{~mm})$, with dark wings, which usually bear pale transversal lines. The male shows complex genitalia and the larvae are morphologically homogeneous. Generic differences were found in the larvae, but the association at the specific level is very difficult. The Neotropical species build typical tortoisecases, often with dorsal respiratory openings. They feed by scraping periphyton from the upper surfaces of rocks

\footnotetext{
* Corresponding author: E-mail: paolamartinzoo@yahoo.com.ar
}

(Wiggins 1996).

In Bolivia and northwestern Argentina four genera have been recorded : Mexitrichia Mosely 1937, Mortoniella Ulmer 1906, Protoptila Banks 1904 and Merionoptila Schmid 1959. Merionoptila is endemic from northwestern Argentina.

Eight species of Glossosomatidae are recorded from northwestern Argentina:

Merionoptila wygodzinskyi Schmid (1959), Mexitrichia albolineata (Ulmer 1907, Mexitrichia pocita Flint (1983), Mexitrichia punensis Flint (1983), Mortoniella argentinica Flint (1974), Mortoniella wygodzinskii (Schmid 1958) , Protoptila dubitans Mosely (1939) and Protoptila misionensis Flint (1972). In Bolivia, five species have been recorded: Mexitrichia bolivica Schmid (1958), Mexitrichia atenuata Flint (1963), Mortoniella paraenchrysa Sykora (1999) and two species shared with Argentina: Mortoniella wygodzinskii and Protoptila dubitans. For both countries, most distributional records are type localities (site from which the species were originally described).

During the past ten years, material of aquatic macronvertebrates was collected in northwestern Argentina. These activities were partially supported by the project "Biodiversity of benthic macroinvertebrates from northwestern Argentina and southern Bolivia". This material is deposited in the collection of Instituto 
Miguel Lillo, and was reviewed for this study. Recent collections were made in Bolivia during the cooperation between the Universities San Andrés of La Paz and San Simon of Cochabamba and the French IRD (Institut de Recherche pour le developpement). In this work, we describe and illustrate seven new species for the first time from Bolivia. We give a new species list and distributional records of Glossosomatidae. All the species collected during this study are illustrated.

\section{Material and methods}

Part of the reviewed material belongs to the Collection of Instituto-Fundación Miguel Lillo. Other material of adult Glossosomatidae was collected recently in Bolivia and Northwestern Argentina and belongs to the Colección Boliviana de Fauna-Instituto de Ecología UMSA (Universidad mayor de San Andrés). Adult specimens were collected in the field with a light trap from sunset to night during about four hours. This material was cleared in a $10 \%$ solution of $\mathrm{NaOH}$ and then neutralized with phenol. The cleared abdomens of males of all collected species were mounted in euparal or in glycerin for observation and illustration. The material mounted in glycerin is preserved and stored in $75 \%$ ethyl alcohol. The material was deposited in the collections of Insituto Miguel Lillo (IML) from Argentina, and in the Bolivian Collection of Fauna of Universidad mayor de San Andrés (CFUMSA). All holotypes were deposited in the IML, and one paratype of each new species was deposited in CFUMSA. The general morphological terminology for Mexitrichia follows that of Flint (1974) and Protoptila terminology follows that of Holzenthal \&Blahnik (2006).

\section{Descriptions}

\section{Mexitrichia collegarum, new species}

This species is close to M. unota Mosely (1939) and M. punensis Flint (1983). Segment X is similar to that of $M$. unota. In lateral view, the dorsomesal process of the phallic apparatus is shorter and more upcurved than in M. punensis; in dorsal view, the tip of the dorsomesal process of M. collegarum, $\mathrm{n}$. sp., is forked.

Adult male. Length of forewings: $2 \mathrm{~mm}$. Color in alcohol: light brown. Sternum VI with compressed small process.

Male genitalia. Segment IX narrowed and enlarged, with anterior margin sinuous (Fig. 1A ix). Tergum $\mathrm{X}$
2 times longer than wide, ventral lobe developed, apex produced into 2 small points in lateral view (Fig. 1A $\mathrm{x}$ ); in dorsal view, with U-shaped mesal excision (Fig. 3B).

Phallic complex. Dorsomesal process upcurved, apex bearing small setae (Fig. 1C dm), in dorsal view, apex is bifid (Fig. 1D dm). Lateral processes paired, sinuous, pointed, half the length of dorsomesal process (Fig

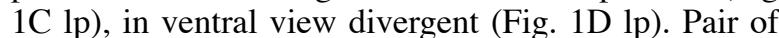
ventral processes short, pointed (Fig 1C vp, 1D vp). Ventral lobe rounded, in lateral view bearing small setae on margin (Fig. $1 \mathrm{C} \mathrm{vl}$ ). Central tube membranous, developed, with 4 dark points at apical extremity (Fig. $1 \mathrm{C}$ ct, 1D ct).

Material examined. Holotype male: BOLIVIA: Tarija: O’Connor: Saladito Ríver, $21^{\circ} 18^{\prime} 28^{\prime \prime} \mathrm{S}, 64^{\circ} 7^{\prime} 2.8^{\prime \prime} \mathrm{W}$, 900 m, 09.x.2004, Molineri \& Manzo cols.; Paratype: 1 adult male; same data as Holotype.

Distribution. M. collegarum n. sp. was found in Saladito river, department Tarija, O’Connor Province, Bolivia.

Etymology. This species is dedicated to the colleagues of the aquatic group from Fundación Miguel Lillo, Tucumán, Argentina.

\section{Mexitrichia eduardoi, new species}

This species is similar to M. velazquezi Flint (1991). Both species share the deeply divided tergum $\mathrm{X}$ and the narrow apicolateral lobe of the tergum $X$.

Adult male. Length of forewings $3 \mathrm{~mm}$. Sternum VI with compressed small process.

Male genitalia. Segment IX with anterior margin slightly oblique and slightly expanded anterolaterally (Fig. 2A ix). Tergum $\mathrm{X}$ with slender apicolateral lobe and small ventrobasal lobe in lateral view (Fig. 2A x); in dorsal view mesal excision broad and deep (fig. 2B). Phallic complex. Dorsomesal process flat, long and upcurved (Fig. 2C dm). Pair of lateral processes slender and sinuous, with apical extremity forked (Fig. 2C lp); in ventral view, pair of lateral processes slightly curved to the midline (Fig. 2D lp). Ventral lobe produced distally into 2 enlarged upcurved lobes as long as the dorsomesal process (Fig. $2 \mathrm{C} \mathrm{vl}$ ), each one bearing dorsal curved and forked sclerotized process (Fig. 2C $\mathrm{fp}$, ) and apical spine; in ventral view dorsal forked processes of ventral enlarged lobes slightly curved to the midline (Fig. 2D fp). Central tube membranous with 2 lateral and one dorsal groups of membranous spines (Fig. 2C ct, 2D ct). 

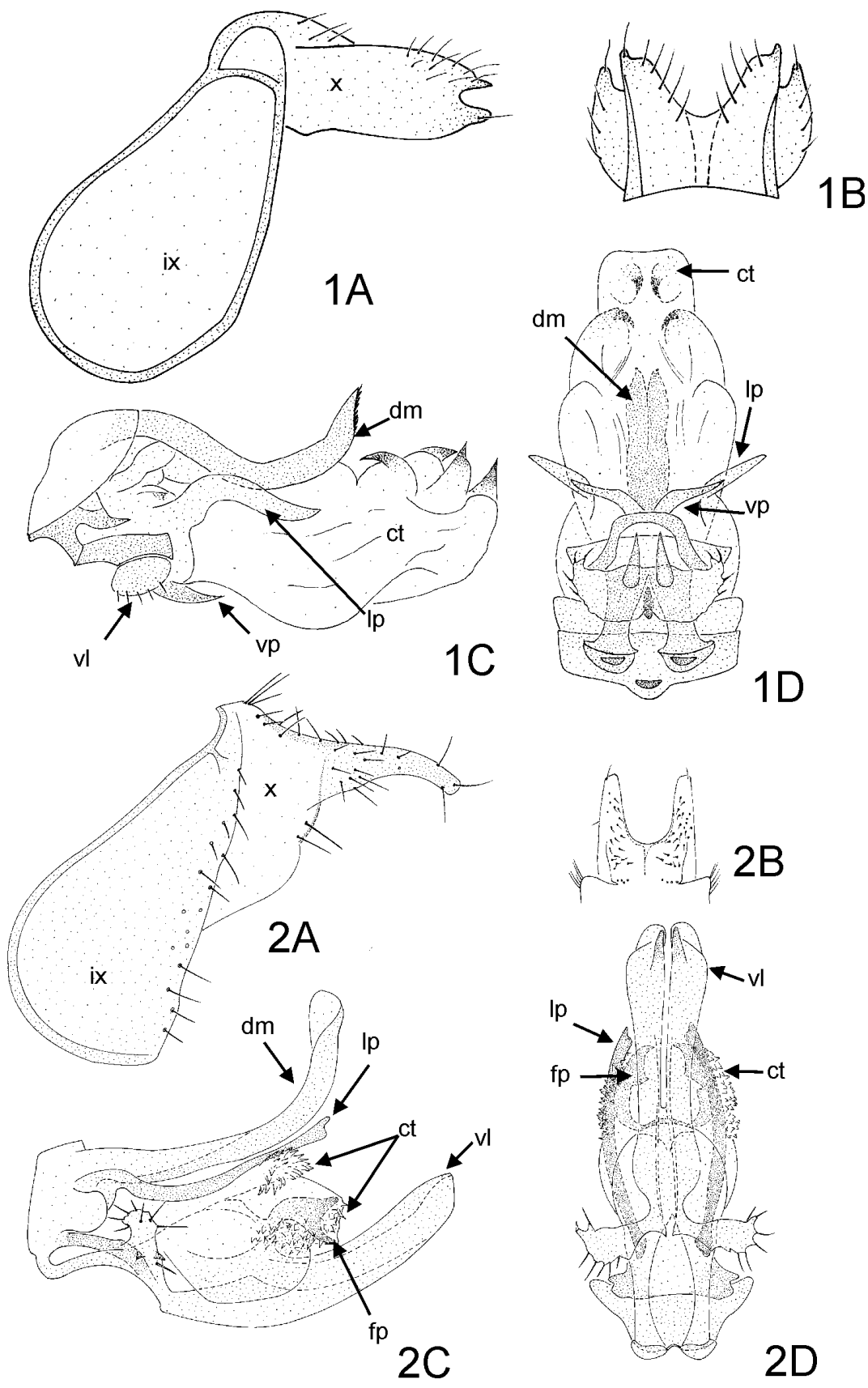

Figs 1-2. (1) Mexitrichia collegarum n. sp., male: A - segments IX and X, lateral view; B - segment X, dorsal view; C - aedeagal complex, lateral view; D - eadeagal complex, ventral view. Abbreviations: ix = segment IX, $\mathrm{x}=$ segment $\mathrm{X}, \mathrm{dm}=$ dorsomesal process, $1 \mathrm{p}=$ lateral process, vl $=$ ventral lobe, $\mathrm{vp}=$ ventral process, $\mathrm{ct}=$ central tube. (2) Mexitrichia eduardoi $\mathrm{n}$. sp., male: A - segments IX and X, lateral view; B - segment $\mathrm{X}$, dorsal view; $\mathrm{C}$ - aedeagal complex, lateral view; $\mathrm{D}$ - eadeagal complex, ventral view. Abbreviations: $\mathrm{ix}=$ segment $\mathrm{IX}, \mathrm{x}=\mathrm{segment} \mathrm{X}, \mathrm{dm}=$ dorsomesal process, $\mathrm{lp}=$ lateral process, $\mathrm{vl}=$ ventral lobe, $\mathrm{fp}=$ forked process, $\mathrm{ct}=$ central tube. 


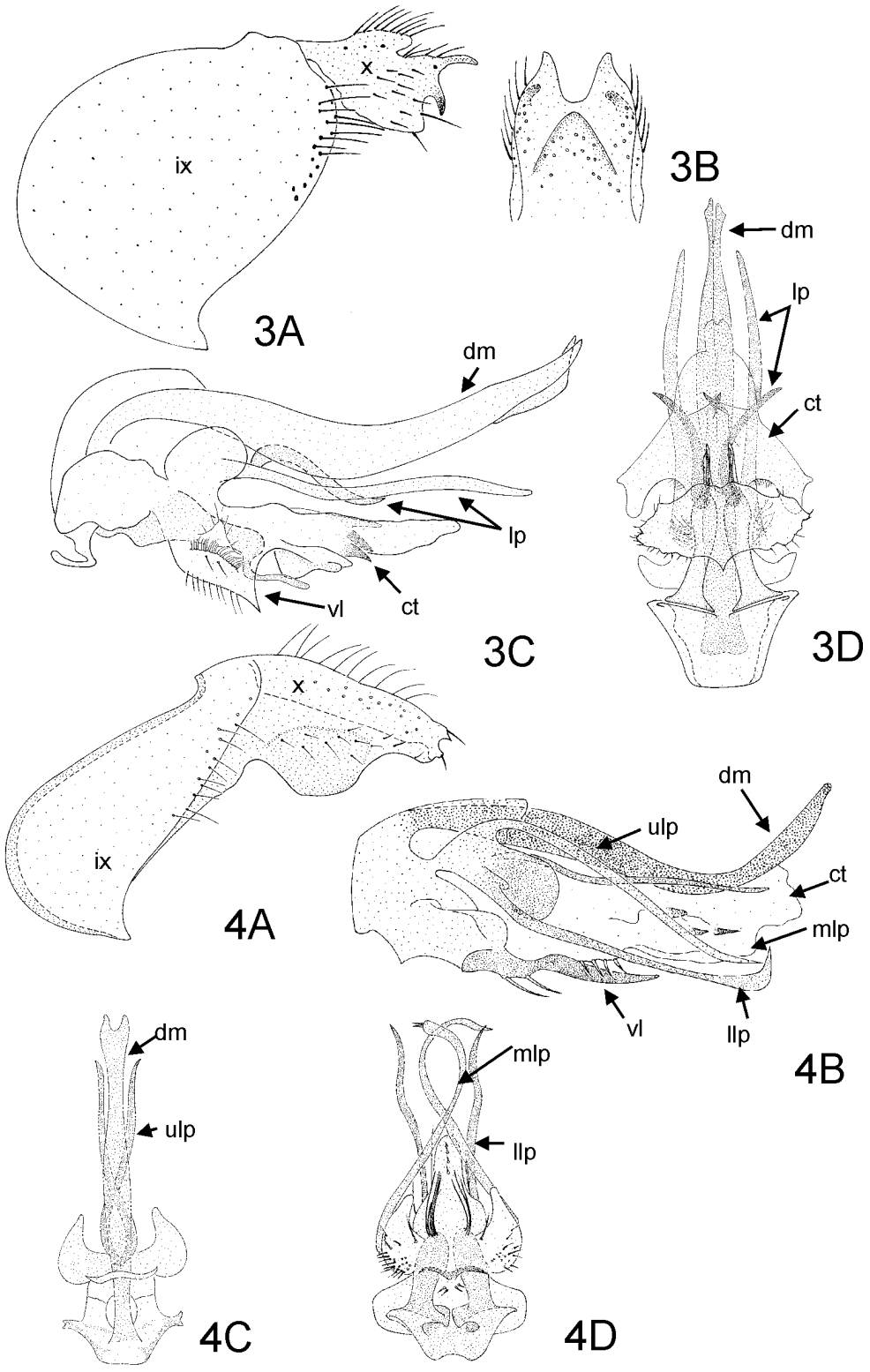

Figs 3-4. (3) Mexitrichia marini n. sp., male: A - segments IX and X, lateral view; B - segment X, dorsal view ; C - aedeagal complex, lateral view; D - eadeagal complex, ventral view. Abbreviations: ix = segment IX, $\mathrm{x}=$ segment $\mathrm{X}, \mathrm{dm}=\mathrm{dorsomesal}$ process, lp $=$ lateral process, $\mathrm{vl}=$ ventral lobe, $\mathrm{ct}=$ central tube. (4) Mexitrichia usseglioi $\mathrm{n}$. sp., male: A - segments IX and X, lateral view; B - aedeagal complex, lateral view; C - aedeagal complex, dorsal view, median and lower lobes removed; D - eadeagal complex, ventral view, upper lobe and dorsomesal lobe reduced. Abbreviations: ix $=$ segment IX, $\mathrm{x}=$ segment $\mathrm{X}, \mathrm{dm}=$ dorsomesal process, $\mathrm{ulp}=$ upper lateral process, mlp $=$ median lateral lobe, $1 \mathrm{lp}$ $=$ lower lateral lobe; $\mathrm{vl}=$ ventral lobe, $\mathrm{ct}=$ central tube. 
Material examined. Holotype male: BOLIVIA: La paz: Yara River near Caranavi, 20.v.2002. Paratype: 1 male adult, Cochabamba: from a small tributary of the Rio Espiritu Santo, (Agrigento near Villa Tunari), 11.ix.2003, 16 $6^{\circ} 58^{\prime} 37^{\prime \prime} \mathrm{S}, 65^{\circ} 23^{\prime} 58^{\prime}$ ”W.

Distribution. Bolivia (La Paz)

Etymology. This species is dedicated to Dr. Eduardo Domínguez, colleague, friend and director of the project: "Biodiversity of benthic macroinvertebrates from northwestern Argentina and southern Bolivia".

\section{Mexitrichia marini new species}

This species is related to M. punensis Flint (1983). The shape of segment $X$ and the two pairs of lateral processes are similar in both species. M. marini, n. sp., may be recognized by the two pairs of hooked apicolateral process of segment $\mathrm{X}$, whereas in $M$. punensis, there is only one pair. The long divided dorsal process of the phallic apparatus is a diagnostic character of this new species, in M. punensis, the apex of dorsomesal process is not divided.

Adult male. Length of forewings $3 \mathrm{~mm}$. Sternum VI with compressed small process.

Male genitalia. Segment IX with anterolateral margin broadly rounded (Fig. 3A ix). Tergum $\mathrm{X}$ in lateral view with apicoventral lobe developed, posterior margin of segment $\mathrm{X}$ bearing dorsal curved process and ventral hooked process decurved to the midline (Fig. 3A x); in dorsal view, tergum $\mathrm{X}$ with mesal excision broad and U-shaped (Fig. 3B).

Phallic complex. Dorsomesal process broad and upcurved in lateral view (Fig. 3C dm); in dorsal view, apex deeply divided (Fig. 3D dm). 2 pair of lateral process, one of which as long as the dorsomesal process ranges from a rounded lobe and the other one shorter, sinuous in lateral view (Fig. 3C lp) and divergent in ventral view (Fig. 3D lp). Ventral lobe lanceolated in lateral view, bearing small setae (Fig. $3 \mathrm{C} \mathrm{vl}$ ). Central tube membranous and developed bearing 2 short ventral spines (Fig. 3C ct, 3D ct).

Material examined: Holotype male: BOLIVIA: La Paz: Small tributary of the Unduavi River at Puente Villa, 21.ii.2002, 16024`03”S, 67038`30”W, F. M. Gibon \& R. Marín cols. Paratype: 1 male adult, same data as Holotype.

Distribution. Bolivia (La Paz).

Etymology. This species is dedicated to our colleague and friend Rubén Marín.

\section{Mexitrichia usseglioi new species}

This species is close to M. macarenica Flint (1974) and M. aequalis Flint (1963). The three species present a similar aspect of segments IX and X. The ventrolateral lobe of tergum $\mathrm{X}$ is as long as the tergum in M. aequalis whereas in $M$. macarenica the ventrolateral lobe is shorter than the tergum and in M. usseglioi it is clearly separated into a rounded lobe. On the phallic apparatus, $M$. aequalis has a single pair of lateral processes, whereas M. macarenica has two pairs and M. usseglioi n. sp. has three pairs.

Adult male. Length of forewings: $3 \mathrm{~mm}$. Sternum VI with a small compressed ventral process.

Male genitalia. Segment IX oblique, with anterior margin sinuous and posterior margin straight (fig. 4A ix). Tergum $X$ in lateral view, with posterior margin produced into two points and ventrolateral lobe well developed (Fig 4 Ax); dorsal view showing a deep mesal excision.

Phallic complex. Dorsomesal process upcurved in lateral view (Fig 4B dm); in dorsal view, dorsomesal process with apical u-shaped excision (Fig. $4 \mathrm{C} \mathrm{dm}$ ). 3 pairs of slender lateral processes: upper pair of lateral processes decurved and pointed in lateral view and crossed in dorsal view (Figs. 4B ulp, 4C ulp); median pair of lateral processes slightly sinuous inserted on a rounded lobe (Figs. 4B mlp, 4D mlp); lower pair of lateral processes slightly decurved posteriorly angulated in lateral view (Fig. 4B llp) crossed into two points in ventral view (Fig. 4D llp). Ventral lobe produced in a ventral process a third of the length of dorsomesal process (Fig. 4B vl). Central tube membranous bearing three sclerotized spines in lateral view (Fig 4B ct).

Material examined. Holotype male: BOLIVIA: Rio Tumusla (not very far from Tumusla and the crossing with the road Potosi-Tupiza), 2.x.2002, O. Fossati and P. Usseglio-Polatera cols. Paratype: 1 male adult, same data as Holotype.

Distribution. Bolivia.

Etymology. This species is dedicated to Philippe Usseglio-Polatera our colleague from the University of Metz, France.

\section{Protoptila alumnorum, new species}

This species and the following $(P$. goitiai) are related to $P$. dubitans Mosely, 1939. The structure of the phallic complex is very similar to that of $P$. dubitans, but $P$. alumnorum can be distinguished by the shape of the 
ventral process of tergum $X$, which is larger, curved and slightly broadened at the tip.

Adult male. Length of forewings: $4 \mathrm{~mm}$. At the sternum VI, short ventral process with rounded apex. Male genitalia. Sternum VIII (lateral view) with posterior margin produced ventrally in a rounded distally-elongated process which bears strong setae (Fig. 5A viii); in ventral view, the posterior apex is slightly concave, bearing setae (Fig. 5B). Segment IX invaginated into segment VIII with anterior margin rounded (Fig 5A ix). Tergum $\mathrm{X}$ with basal section rounded and bearing setae; apical section with 2 pairs of ventral projections and a dorsal small process (lateral view, Fig. $5 \mathrm{~A} \mathrm{x}$ ); ventral process of tergum $\mathrm{X}$ curved and slightly broadened at the tip with pointed apex (Fig. $5 \mathrm{~A} v \mathrm{vp}$ ).

Phallic complex. Phallobase dorsally with large laterally compressed apodeme (Fig. 5C ap); ventrally with rod-like, articulated appendages with apical setae, which bears a hooked process (Figs. 5C art, 5D art). Basal process sinuous with truncated extreme (Figs. 5C bp, 5D bp). Dorsolateral process pointed and decurved (Figs. 5c dlp, 5D dlp). Paramere with membranous basal portion and sclerotized apical portion bearing ventrallydirected spines (Figs. 5C par, 5D par). Phallicata with ventral surface sclerotized, slightly broadened at the tip (Fig. 5C ph); endophallus membranous with rounded apex, apex biphid in dorsal view (Fig. 5C e, 5d e); phallotremal sclerite internal, pointed, curved, and apically-sclerotized.

Material examined. Holotype male: BOLIVIA: Rio Yara, at the crossing with the road Caranavi/Quiquibey, 20.xii.02, F.-M. Gibon col.; Paratype: 1 male adult, same data as Holotype.

Distribution. Bolivia, Yungas de La Paz.

Etymology. This species is dedicated to the students of the school which is situated at the type-locality.

\section{Protoptila goitiai, new species}

Protoptila goitiai, n. sp. is related to $P$. dubitans Mosely, 1939. The structure of the genitalia is similar in both species, but the new species principally differs in the mesal excision of segment VII which is deeper, the shape of tergum X, and the shape of ventral process of segment $X$, which is larger.

Adult male. Length of forewings: $3 \mathrm{~mm}$.

Male genitalia. At the sternun VI, the ventral process is prominent, broad with a subacute apex. Segment VIII with posterior margin produced into a ventral process which bears setae (lateral view: Fig. 6A viii); in ventral view, apex broadly divided in a U-shaped excision (Fig. 6B). Segment IX invaginated into segment VIII (Fig. 6A ix). Tergum $X$ subtriangular (Fig. 6A x), slightly decurved with ventro-apical lobe which bears small superficial grains; ventral process of tergum $\mathrm{X}$ slightly angulated with truncated apex (Fig. 6A vp).

Phallic complex. Phallobase dorsally with large laterally compresed apodeme (Fig. 6C ap); ventrally with articulated appendages with apical setae which can not be seen laterally (Fig. 6D art). Basal process short with apex truncated in lateral view, and pointed in ventral view (Figs. 6C bp, 6D bp). Dorsolateral process as long as basal process with pointed ventrallydirected apex (Figs. 6C dlp, 6D dlp). Paramere with membranous basal section and apical section bearing strong curved spine (Figs. 6C par, 6D par). Phallicata long and slender (Fig. 6C ph); endophallus membranous with apex rounded in lateral view and biphid in ventral view (Figs. 6C e, 6D e); phallotremal sclerite V-shaped in ventral view.

Material examined: Holotype: male: Bolivia: Cochabamba: from a small tributary of the Rio Espiritu Santo (Chipiriri near Villa Tunari), 25.ix.2003, 16 $50^{\circ} 45^{\prime \prime}$ S, $65^{\circ} 25^{\prime} 33^{\prime \prime} \mathrm{W}$, E. Goitia col. Paratype: 1 male adult, same data as Holotype

Etmology. This species is dedicated to our friend and colleague Edgar Goitia.

\section{Protoptila myriamae, new species}

Protoptila myriamae, n. sp. is related to P. simplex Flint, 1971. The structure of segment VIII and IX are similar in both species. P. myriamae, n. sp. differs principally in the shape of tergum $X$ which bears a basal lobe and a pair of apical lobes bearing two ventral teeth. The phallic complex is similar in both species, but in P. myriamae n. sp. the base of the paramere is membranous and the apex is pointed and sinuous.

Adult male. Length of forewings: $4 \mathrm{~mm}$.

Male genitalia. Sternum VI with long setae, distinct from the ventral process, which is short. Sternum VIII broad with posterior margin produced, bearing ventral setae and a strong apical tooth (Fig. 7A viii); in ventral view, posterior margin with broad basis and U-shaped excision(Fig. 7B). Segment IX invaginated into segment VIII, anterior margin sinuous (Fig. 7A ix). Tergum $\mathrm{X}$ fused to tergum IX (Fig. 7A x), bearing latero-basal subrectangular lobe; ventral process laterally flattened 

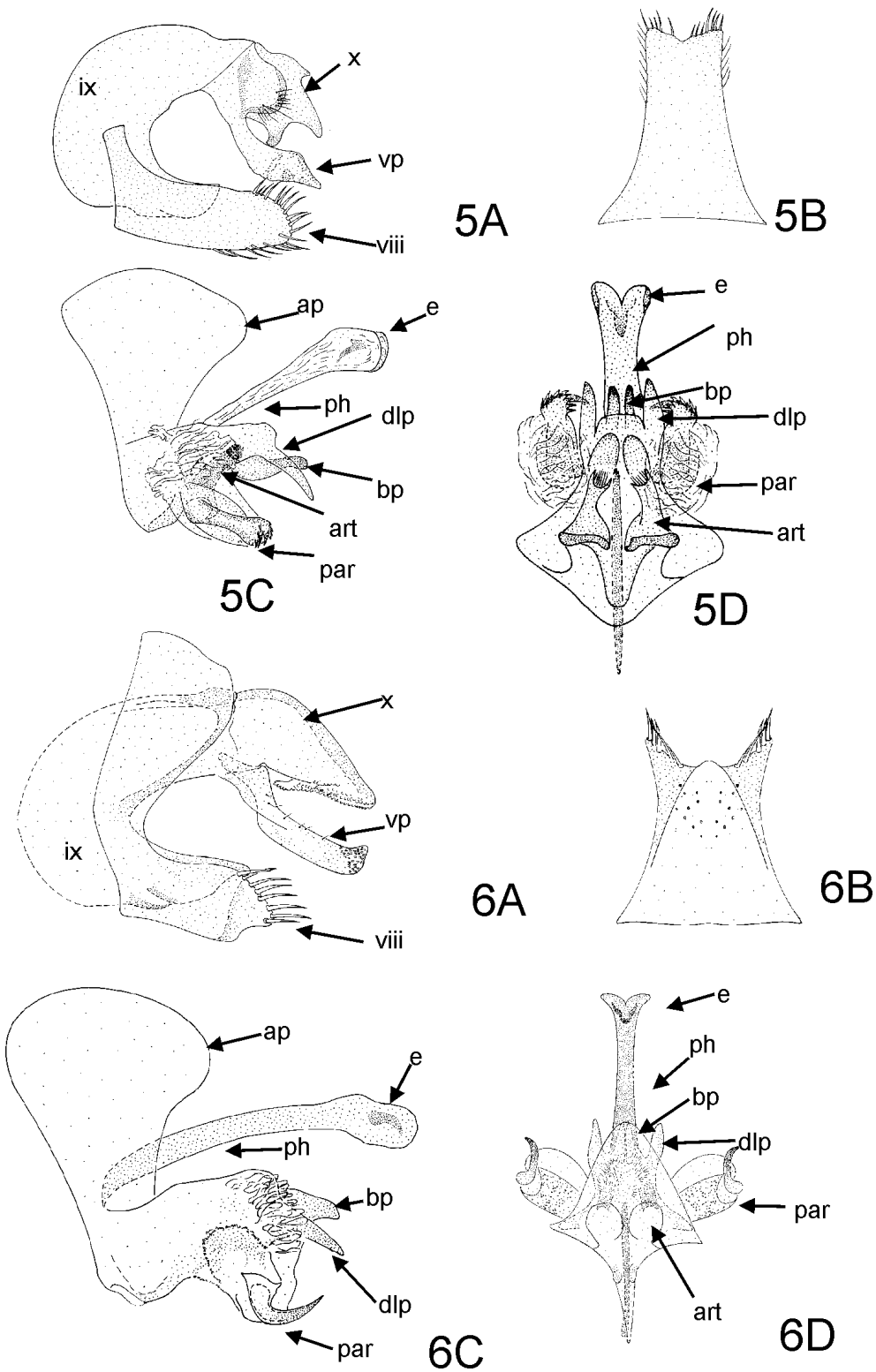

Figs 5-6. (5) Protoptila alumnorum n. sp., male: A - segments VIII, IX and X, lateral view; B - segment VIII, ventral view; C - phallic complex, lateral view; D - phallic complex, ventral view. Abbreviations: viii = segment VIII, $i x=$ segment IX, $x=$ segment X, vp $=$ ventral process of segment $\mathrm{X}, \mathrm{ap}=$ apodeme, art $=$ articulated appedages, $\mathrm{bp}=$ basal process, $\mathrm{dlp}=$ dorsolateral process, par $=\mathrm{paramere}, \mathrm{ph}=\mathrm{phallobase}, \mathrm{e}=$ endophallus. (6) Protoptila goitiai. sp., male: A - segments VIII, IX and X, lateral view; B - segment VIII, ventral view; C - phallic complex, lateral view; D - phallic complex, ventral view. Abbreviations: viii $=$ segment VIII, ix $=$ segment IX, $x=$ segment $X$, vp $=$ ventral process of segment $\mathrm{X}, \mathrm{ap}=$ apodeme, art $=$ articulated appedages, $\mathrm{bp}=$ basal process, dlp $=$ dorsolateral process, par $=$ paramere, $\mathrm{ph}=$ phallobase, $\mathrm{e}=$ endophallus. 

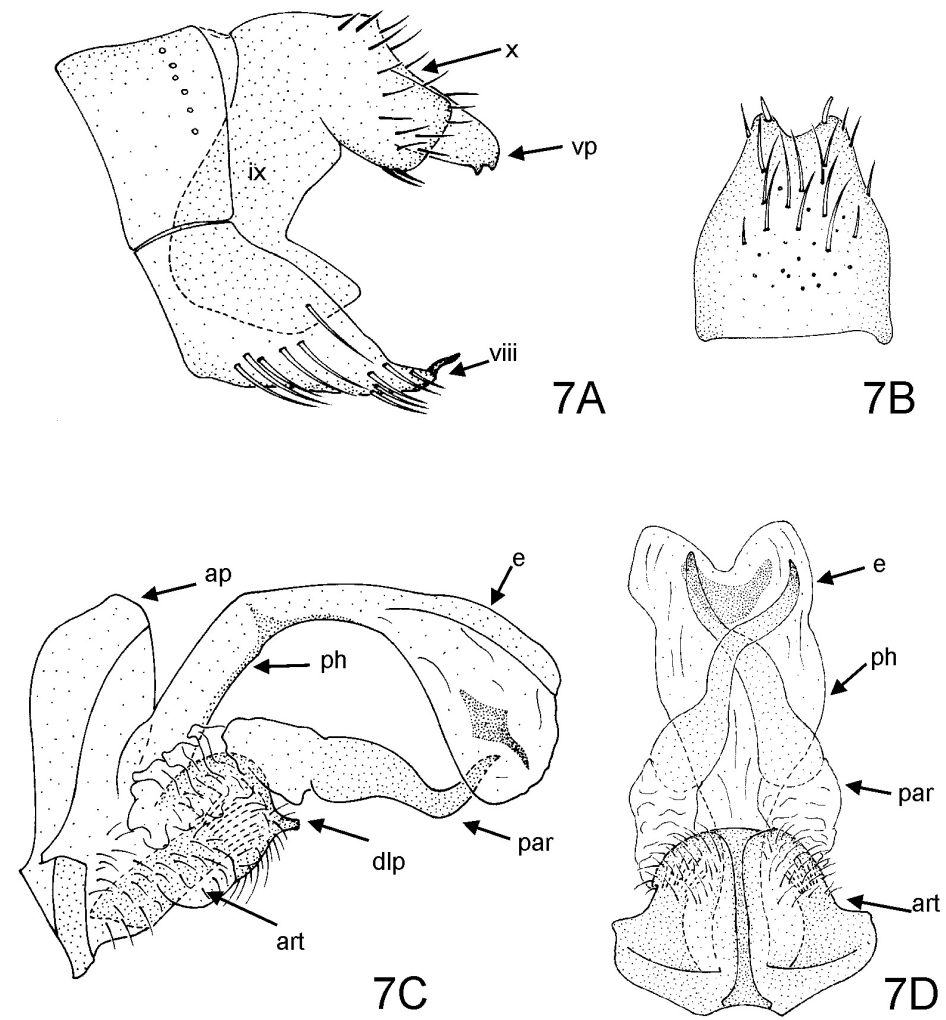

Fig7. Protoptila myriamae n. sp., male: A - segments VIII, IX and X, lateral view; B - segment VIII, ventral view; C - phallic complex, lateral view; D - phallic complex, ventral view. Abbreviations: viii = segment VIII, ix= segment IX, $x=$ segment $X$, vp = ventral process of segment $X$, $\mathrm{ap}=$ apodeme, art $=$ articulated appedages, $\mathrm{dlp}=$ dorsolateral process, par $=$ paramere, $\mathrm{ph}=$ phallobase, $\mathrm{e}=$ endophallus.

with a rounded apex and two apicoventral teeth (Fig. 7A vp).

Phallic complex. Phallobase dorsally with small laterally compresed apodeme (Fig. 7C ap); ventrally with articulated appendages bearing apical setae produced into a pocket (Figs. 7C art, 7D art). Basal process reduced; dorsolateral process small and rod-like (Figs. 7C dlp, 7D dlp). Paramere with basal section membranous, apical section sinuous, pointed (lateral view), and crossed (ventral view) (Figs. 7C par, 7D par). Phallicata long and angulated, ventrally reinforced; in dorsal view, the basis is narrow and the tip is broad (Figs. 7C ph, 7D ph); endophallus membranous broad and biphid (ventral view: Figs. 7C e, 7D e), phallotremal sclerite spine-like in lateral view, curved and sclerotized in ventral view posteriorly rounded.

Holotype: male: BOLIVIA: Rio Ilenez in Versalles, 04.v.06, 12³9`39”S, 63²2`22”W, F-M. Gibon and C. Molina cols. Paratype: 4 male adults, same data as holotype.

Distribution. Bolivia.

Etymology. This species is dedicated to Prof. María Elvira Martín, who usually is called Myriam. Prof. María Elvira is the mother of Lic. Paola Alejandra Rueda Martín, first author of this paper.

\section{Chek list of the Glossosomatidae from North- western Argentina and Bolivia}

Merionoptila Schmid, 1959. Distribution: Northwestern Argentina.

M. wygodzinskyi (Schmid, 1959). Distribution: Argentina (Tucumán). Schmid 1959, p. 482.

Mexitrichia Mosely, 1939. Distribution: South and 

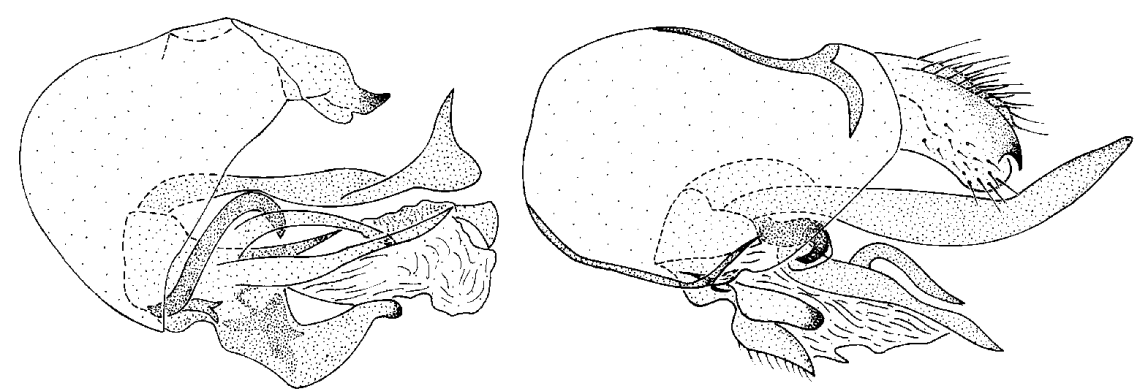

8

9

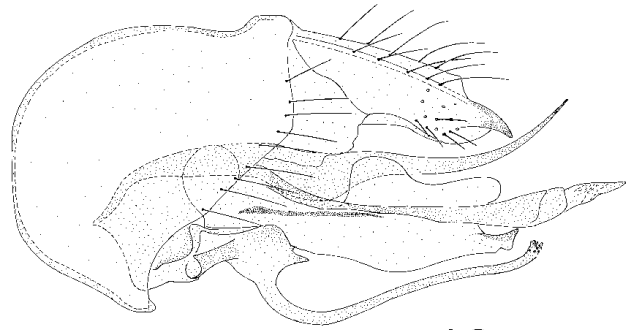

10

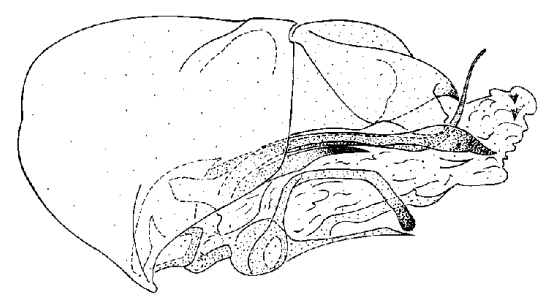

11

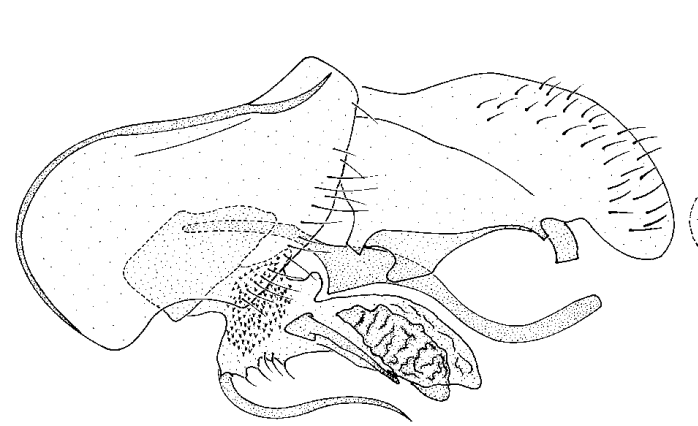

12

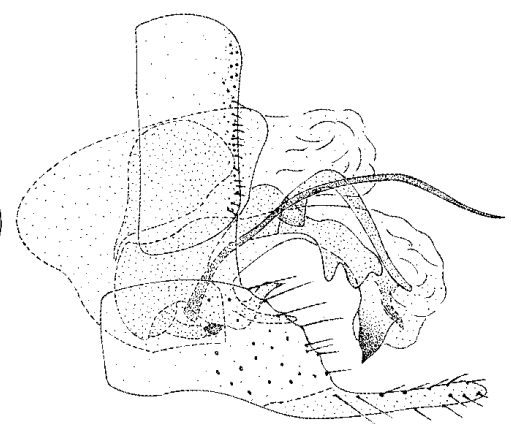

13

Fig 8-13. (8) Mexitrichia pocita, (9) M. punensis, (10) M. simla, (11) Mortoniella argentinica, (12) M. wygodzinskyi, (13) Protoptila misionensis.

Central America.

M. albolineata (Ulmer, 1907). Distribution: Argentina (Salta, Misiones), Brazil, Uruguay. Flint (1966, 1972).

Mortoniella spp. Ulmer 1906.

Mortoniella albolineata Ulmer (1907); Jörgensen (1919); Tomaszewski (1961); Fischer (1961).

M. bolivica Schmid, 1958. Distribution: Bolivia (Coroico). Schmid 1958, p.193

Mexitrichia eduardoi new species (Fig. 1). Distribution:
Bolivia.

Mexitrichia marini new species (Fig. 2). Distribution: Bolivia.

M. pocita Flint, 1983 (Fig. 8). Distribution: Argentina (Salta), Flint 1983, p.8. (Fig.25); Bolivia new record (Tarija, Río Saladito, 10.x.2004).

M. punensis Flint, 1983 (Fig. 9). Distribution: Argentina (Tucumán) Flint 1983, p.8. (Fig. 26); Bolivia new record (Tarija, Río Orosa, 4.x.2004).

M. collegarum, new species (Fig. 3). Distribution: 
Argentina (Salta), Bolivia (Tarija).

M. simla Flint, 1974 (Fig.10). Distribution: Venezuela Flint 1974, p.11, Flint (1996); Trinidad Botosaneanu and Alkins Koo (1993); Bolivia new record (Río Agrigento, 11.ix.2003).

The Bolivian specimens have the lateral process on the phallic apparatus longer than in the original description (Fig 10), probably as consequence of the process of cleared. This difference was not considered as interspeciphic because the differences between the described species of this genus are based in more important variations of caracters.

Mexitrichia usseglioi new species (Fig. 4). Distribution: Bolivia.

Mortoniella Ulmer, 1906. Distribution: western of South and Central America.

M. argentinica Flint, 1974 (Fig. 11). Distribution: Argentina (Catamarca; Tucumán new record, Parque Nacional Los Alisos, Río Pavas, 24.ix.2006). Flint 1974, p.13. (Fig.28)

M. paraenchrysa Sykora, 1999. Distribution: Bolivia (Coroico) Sykora 1999, p.381.

M. wygodzinskii (Schmid, 1958) (Fig. 12). Flint, 1963 (synonymy). Distribution: Argentina (Tucumán; Salta new record, Río Huaico Grande, 11.xi.2004) Schmid 1958, p.154; Bolivia (La paz), Ecuador, Venezuela, Sykora (1999). (Fig. 29). Knutson and Flint (1979).

Protoptila Banks, 1904. Distribution: America.

Protoptila alumnorum new species (Fig. 5). Distribution: Bolivia.

P. dubitans Mosely, 1939. Distribution: Argentina (Córdoba, Tucumán. Salta) Bolivia (Tarija) Cohen, 2004; Brazil (N. Teutona, Minas Gerais) Mosely 1939, p.221, Uruguay (Artigas Salta, Pasandu) Angrisano (1997); Flint (1963, 1982).

Protoptila goitiai new species (Fig. 6). Distribution: Bolivia.

P. misionensis Flint, 1972 (Fig.13). Distribution: Argentina (Misiones; Salta; Jujuy; Tucumán new record, Río Pueblo Viejo, 4.v.2005) Flint 1972, p.226. (Fig. 30); Bolivia new record (Río Las Pozas, 10.ix.2003).

Protoptila myriamae new species (Fig. 7). Distribution: Bolivia.

\section{Acknowledgments}

We wish to thank E. Domínguez for reading the manuscript and giving valuable comments and corrections. Thanks also to the aquatic group from INSUE for assistance and help in collecting and to Dr. Carlos Molineri and Lic. Verónica Manzo, who provided part of the necessary material from Bolivia. This manuscript was done with an internal fellowship from CONICET (National Council of Scientific Research, Argentina) and financially supported by: CONICET PIP 01-02563/98, "Agencia Nacional de Promoción Científica y Tecnológica" PIP 01-12529/02, "Consejo de Investigaciones de la Universidad Nacional de Tucumán” CIUNT 26G309 (2005/2008).

\section{References}

Angrisano E.B. 1995. El Orden Trichoptera en la Argentina y paises limítrofes. Physis (Buenos Aires). Secc. B, 50 (118-119), 19-25.

Angrisano E.B. 1997. Los Trichoptera de Uruguay. III. Familias Philopotamidae, Hydrobiosidae, y Glossosomatidae. Rev. Soc. Entomol. Argent. 56, 55-58.

Banks N. 1904. A List of New Neuropteroid Insects, Exclusive of Odonata, from Vicinity of Washington, D. C. Proc. Entomol. Soc. Wash., 6, 201-217.

Botosaneanu L. \& Alkins Koo M. 1993. The caddis flies (Insecta: Trichoptera) of Trinidad and Tobago, West Indies. B. I. Roy. Sci. Nat. Belg., Entomol., 63, 5-45.

Fischer F.C.J. 1961. Philopotamidae, Hydroptilidae, Stenopsychidae. Trichopterum Catalogus, 2, iv+169.

Flint O.S. Jr. 1963. Studies of Neotropical Caddisflies, I: Rhyacophilidae and Glossosomatidae (Trichoptera). Proc. Natl. Mus., 114, 453-478.

Flint O.S. Jr. 1966. Studies of Neotropical caddis flies, III: types of some species described by Ulmer and Brauer. Proc. U. S. Natl. Mus., 120(3559), 1-20.

Flint O.S. Jr. 1971. Studies of Neotropical caddis flies, XII: Rhyacophilidae, Glossosomatidae, Philopotamidae, and Psychomiidae from the Amazon Basin (Trichoptera). Amazoniana, III (1), 1-67.

Flint, O.S. Jr. 1972. Studies of Neotropical caddis flies, XIV: on a collection from northern Argentina. Proc. Biol. Soc. Wash., 85, 223-248.

Flint O.S. Jr. 1974. Studies of Neotropical Caddisflies XVIII: New species of Rhyacophilidae and Glossosomatidae. Smith. Contr. Zool, 169, 1-30.

Flint O.S. Jr. 1982. Trichoptera del Area Platense. Biol. Acuát., 213, $1-70$.

Flint O.S. Jr. 1983. Studies of Neotropical caddisflies, XXXIII: new species from austral South America (Trichoptera). Smith. Contr. Zool, 377, 1-100.

Flint O.S. Jr. 1991. Studies of Neotropical Caddisflies, XLV: The taxonomy, phenology, and faunistics of the Trichoptera of Antioquia, Colombia. Smith. Contr. Zool, 520, 1-113.

Flint O.S. Jr. 1996. Studies of Neotropical caddisflies, LV: Trichoptera of Trinidad and Tobago. T. Am. Entomol. Soc., 122, 67-113.

Flint O.S. Jr., Holzenthal R., \& Harris S.C. 1999. Catalog of the Neotropical Caddisflies (Insecta: Trichoptera). Columbus, Ohio, iv+239pp.

Holzenthal R.H. \& Blahnik R.J. 2006. The Caddisfly genus Protoptila in Costa Rica (Trichoptera: Glossosomatidae). Zootaxa, 1197, $1-37$.

Jörgensen P. 1919. Los trichópteros Argentinos. Primera Reunión Nacional de la Sociedad Argentina de Ciencias Naturales, Tucumán (1916), 389-399.

Knutson L. \& Flint O.S. Jr. 1979. Do dance flies feed on caddisflies?further evidence (Diptera: Empididae; Trichoptera. Proc. Entomol. Soc. Wash, 81, 32-33.

Morrone J. J. 2001. Biogeografía de América Latina y el Caribe. Manuales y Tesis SEA, 3, Zaragoza (España), 148 pp.

Mosely M.E. 1937. Mexican Hydroptilidae (Trichoptera). Trans.R. Entomo. Soc. Lond., 86, 151-190. 
Mosely M.E. 1939. The Brazilian Hydroptilidae (Trichoptera). Novitates Zool. 41, 217-239.

Schmid F. 1958. Contribution à l'étude des Trichoptères néotropicaux III. Mitteilungen aus dem Zoologischem Museum in Berlin, 34, 183-217.

Schmid F. 1959. Contribution à l'étude des Trichoptères néotropicaux IV. Acta Zool. Lilloana, 17, 477-483.

Sykora J.L. 1999. Genus Mortoniella and its distributions in South America (Trichoptera, Glossosomatidae, Protoptilinae). Pages 377-387. In H. Malicky and P. Chantaramongkol, editors, Proc $9^{\text {th }}$ International Symposium on Trichoptera, xiii+479pp. Chiang Mai,

Thailand: Faculty of Science, Chiang Mai Univ.

Tomaszewsk C. 1961. List of the Type specimens in the collection of the Institute of Zoology, of the Polish Academy of Sciences in Warsaw, IV: Caddis Flies (Trichoptera). Ann. Zoologici, 20, 1-6.

Ulmer G. 1906. Neue Beitrag zur Kenntnis aussereuropaeischer Trichopteren. N. Leyden Mus., 28, 1-116.

Ulmer G. 1907. Neue Trichopteren. N. Leyden Mus., 29, 1-53.

Wiggins GB. 1996. Larvae of the North American caddisfly Genera (Trichoptera). $2^{\text {nd }}$ Edition, University of Toronto Press. Toronto \& Buffalo, 457 pp. 